\title{
ASSESSMENT OF CARCINOGENIC POTENTIAL OF SOFT DRINKS OF COLA, DIET COLA, ORANGE AND LEMON, PRODUCED IN THE CITY OF UBERLÂNDIA, MINAS GERAIS STATE, BRAZIL
}

\author{
AVALIAÇÃO DO POTENCIAL CARCINOGÊENICO DE REFRIGERANTES À BASE \\ DE COLA, DIET COLA, LARANJA E LIMÃO, PRODUZIDOS NO MUNICÍPIO DE \\ UBERLÂNDIA, ESTADO DE MINAS GERAIS, BRASIL
}

\author{
Cássio Resende de MORAIS'; Thays Cunha VIEIRA²; Renato Mendonça BORGES ${ }^{3}$; \\ Luisa Mariana Melo GUIMARÃES ${ }^{3}$; Lucas Almeida BARCELOS ${ }^{3}$; \\ Fernanda Carvalho de SOUZA ${ }^{3}$; Leticia Santos PIMENTEL ${ }^{3}$; Jéssica Costa da SILVA ${ }^{4}$; \\ Mirley Alves VASCONCELOS ${ }^{5}$; Tamiris Sabrina RODRIGUES ${ }^{5}$; \\ Francielle Aparecida de SOUSA ${ }^{6}$; Alexandre Azenha Alves de REZENDE $^{7}$; \\ Mário Antônio SPANÓ ${ }^{7}$; Ana Maria BONETTI ${ }^{7}$.
}

1. PhD. Student, Universidade Federal de Uberlândia, Uberlândia, MG, Brazil. cassio.1015@ hotmail.com; 2. Student, Fundação Carmelitana Mário Palmério, Monte Carmelo, MG, Brazil; 3. Student, Universidade Federal de Uberlândia, Uberlândia, MG, Brazil; 4. Student, Universidade Federal de Pernambuco, PE, Brazil; 5. Mastering student, Universidade Federal de Uberlândia, MG, Brazil; 6. Master professor, Fundação Carmelitana Mário Palmério, MG, Brazil; 7. Professor (a), PhD., Universidade Federal de Uberlândia, MG, Brazil.

\begin{abstract}
Soft drinks are industrialized unfermented beverages, free of alcohol, carbonated, rich in artificial flavors and sugar. The intense consumption of such beverages can be related to not inheritable diseases such as caries, allergy, cellulite and stretch marks, gastrointestinal disorders, diabetes and cancer. The aim of this study was to evaluate the carcinogenic potential of different concentrations of soft drinks produced in the Uberlândia city, Minas Gerais State, Brazil, by means of Epithelial Tumor Detection Test using Drosophila melanogaster as a model. Third stage larvae descendants of crosses between $D$. melanogaster virgin females $w t s / T M 3, s b^{1}$ and males $m w h / m w h$ were treated with different concentrations $(0.83,1.66$ or $3.33 \mathrm{~mL} / \mathrm{g})$ of cola, diet cola, orange or lemon soft drinks. The total epithelial tumor rate observed in flies treated with $3.33 \mathrm{~mL} / \mathrm{g}$ of cola and orange soft drinks was higher than the negative control. The diet cola and lemon caused no significant increase in the overall frequency of epithelial tumors in D. melanogaster. In conclusion, in these experimental conditions, the cola and orange base soft drinks demonstrated carcinogenic potential in somatic cells of D. melanogaster in the concentration of $3.33 \mathrm{~mL} / \mathrm{g}$.
\end{abstract}

KEYWORDS: Mutagenicity wts. Warts. Drosophila melanogaster.

\section{INTRODUCTION}

According to the Brazilian Association of Soft Drink Industries and Spirits (ABIR), soda can be defined as an industrialized unfermented drink free of alcohol, carbonated, rich in artificial flavors and sugar, with high cooling power (CARMO, 2006). In Brazil, cola, lemon, orange and grapefruit based soft drinks are the most marketed and is widely used by people in different age groups (CARMO, 2006; OLIVEIRA et al., 2011).

Basically, the composition of the soft drinks is water, sugar (sucrose), concentrate (essential oils, extracts or fruit juice), acidulants (citric, phosphoric or tartaric acid), antioxidants, preservatives, colorants, sweeteners (sweeteners replacing sucrose) and carbon dioxide (carbonic acid).

Excessive consumption of soft drinks is worrying from the medical point of view, since due to the large amount of sugar in these drinks, the high consumption can lead to physiological changes in the body (REIS et al., 2010; OLIVEIRA et al., 2011). Due to non-activation of the satiety centers when compared to solid food, the consumption of soft drinks can lead to greater energy intake, resulting in medical conditions related to obesity. Added to this fact the consumption of these drinks is directly related to increased tooth decay and glycemic diseases such as diabetes (CARMO, 2006).

Soft drink consumption may reduce or replace the intake of other beverages of nutritional value in meals such as milk or natural juice, compromising the stiffness of bone tissue and lead to the emergence of osteoporosis because the calcium restriction in the body (GARCIA et al., 2003; LUDWIG et al., 2001; BOWMAN, 2002; NIELSEN and POPKIN, 2004; KELLER et al., 2009). 
Ingredients contained in the formulation of soft drinks, such as acidulants, preservatives and artificial colorants have been described as being harmful to health and may result in the appearance of allergic conditions, hyperactivity, cellulitis subcutaneous formation, gastrointestinal disorders and neoplastic cells (CARVALHO, 2006).

A few decades ago, genetic analyzes have become essential for understanding the pathophysiology of disease, as they provide the basis for understanding the cellular functions that are controlled by the expression of protein-coding genes and functional enzymes and / or genes encoding non-protein components (LOURO et al., 2002).

Deoxyribonucleic acid (DNA) often has its bases exposed to natural or artificial agents that can cause changes in their chemical structure or composition. Lesions in the genetic material are commonly caused by spontaneous errors or exposure to chemical, physical and biological agents (FRANK, 2010).

Aggressive events to genetic material could compromise the process of replication and gene transcription, as well as the normal segregation of chromosomes. These lesions tend to be repaired by enzymes of the DNA repair machinery. However, if the carrier cell to divide a mutation completely before the repair is done, this mutation could be fixed and become a permanent change (KIM et al., 2011).

Mutations above basal tolerance, may also affect genes necessary for cell's survival or genes involved in cell cycle control. In the latter case, this change can lead to uncontrolled cell proliferation, with the consequent appearance of tumor frames (HIB; ROBERTIS, 1998; COSTA; MENK, 2000).

The cell proliferation cycle is strictly controlled, however, cancer cells, which do not undergo the cooperation scheme, are cells with altered DNA that escape the cell cycle control mechanisms (LOPES et al., 2002).

Two broad categories of genes are highlighted: the proto-oncogenes and tumor suppressor genes (READ; STRACHAN, 2002). Proto-oncogenes are genes related to growth, differentiation and cellular proliferation (LOPES et al., 2002). The tumor suppressor genes imposes some limits to the cycle and cell growth and suppress some characteristics of tumor cells, acting as an anti-neoplastic agent.

The Genetic Toxicology has turned its attention to the investigation of mutagenic and carcinogenic agents (MACHADO et al., 2013), as well as to standardize protocols and tests as tools for detecting point mutations, chromosomal aberrations and aneuploidy events (ANDRADE; LEHMANN, 2003). The use of model organism with intrinsic specific characteristics (sensitivity and response) is a crucial part for validating a test.

The D. melanogaster is a versatile model of organism responsible for providing important information on genetic studies and development (KIM et al., 2011). After sequencing the human genome was found $75 \%$ of homology with of human disease-related genes, allowing the extrapolation of the results obtained in D. melanogaster for humans.

The Epithelial Tumor Detection Test in $D$. melanogaster is a test used to diagnose tumor in flies, caused by xenobiotics (SIDOROV et al., 2001; ORSOLIN; NEPOMUCENO, 2009; SILVA; NEPOMUCENO, 2011; COSTA et al., 2011; FURTADO; NEPOMUCENO, 2012; ORSOLIN et al., 2012). This test uses the strain of $D$. melanogaster having the marker wts (Warts) gene, that when expressed in the wild condition acts as a tumor suppressor gene (XU et al., 1995). The gene deletion and subsequent expression of recessive allele leads to the formation of cells clones that are highly invasives, leading to the manifestation of epithelial tumor in the body and fly appendages (NISHIYAMA et al., 1999).

By means of the Epithelial Tumor Detection Test in D. melanogaster this study aimed to evaluate the carcinogenic potential of cola, diet cola, orange and lemon soft drinks in different concentrations.

\section{MATERIAL AND METHODS}

\section{Chemical Agents}

Cola-based with sugar, lot: LP061214, diet cola-based, lot: LP101214, orange-based lot: LP190115, lemon-based lot: LP220115 were obtained from Uberlândia Refrescos (Uberlândia, MG, Brazil).

Mitomycin C (CAS 50-07-7), lot: 940201, as lyophilized powder (Kyowa Hakko Kirin Co. Ltda. Shizuoka (Japan), packaged by Squibb S.r.1 Sermoneta-Latina-Itália and imported by BristolMyers Squibb Farmacêutica S.A.

\section{Ephitelial tumor detection test in D. melanogaster Drosophila stocks, crossing and treatments}

Two mutant strains were used in this test: multiple wing hairs ( $m w h, 3-0,3)$ and warts (wts,3100). The multiple wing hairs stock is maintained in recessive homozygosis for the marker $m w h$, located at chromosome 3 , in a distal position from centromere ( $m w h, 3-0.3)$. When expressed in recessive homozygosis, $m w h$ gene produces 
multiple hairs phenotype in the fly wings, different from wild type (a single hair by cell).

The warts stock has the marker wts gene at chromosome 3 , maintained in hemizygous in the presence of balancer chromosome named $T M 3, S b^{l}$. The wild condition of the wts marker acts as tumor suppressor gene. The deletion of this gene, or expression of the recessive allele, leads to cellular clones formation highly invasive, that causes epithelial tumor in the fly body and appendices.

These stocks were maintained in bottles containing $1 / 4$ banana-based medium $(1230.0 \mathrm{~mL}$ water; $16.5 \mathrm{~g}$ agar; $234 \mathrm{~g}$ banana; $37.5 \mathrm{~g}$ yeast Saccharomyces cerevisiae and 1.5 nipagin) in B.O.D incubator (SOLAB) under light/dark cycles at $25.0 \pm 2.0{ }^{\circ} \mathrm{C}$ e $65.0 \pm 5.0 \%$ of relative humidity.

The crossing was performed between $m w h / m w h$ males and virgin wts females [1] in [1] kni [ri-1] p [p] wts [3-17]/TM3,S B [1]. Two different progenies were obtained from this crossing: MH progeny, marked trans-heterozygous $(m w h+/+w t s)$ and $\mathrm{BH}$ progeny, balanced heterozygous $\left(m w h+/+\mathrm{TM} 3, \quad \mathrm{Sb}^{1}\right)$. Only $\mathrm{MH}$ progeny is analyzed, which is identified by expression of balancer chromosome TM3, $S b^{1}$, showing stubby hairs phenotype in the fly body, differing from $\mathrm{MH}$ progeny, with long thin hairs phenotype.

Egg collection from crossing $m w h+/+m w h \mathrm{x}$ $w t s+/ T M 3, S b^{1}$ was done during 8 hours in the bottles with agar-based medium $(4.0 \%)$ and sucrosesupplement yeast. After $72 \pm 4$ hours, third stage larvae were washed with ultrapure water Milli-Q (Millipore) and collected using fine mesh sieve. The larvae were transferred to vials $(2.5 \mathrm{~cm}$ diameter by $8.0 \mathrm{~cm}$ length) containing $1.5 \mathrm{~g}$ of instant mashed potatoes (Yoki ${ }^{\circledR}$ Alimentos S.A., lot: T1LH4FH) and $5.0 \mathrm{~mL}$ of soft drinks. The concentrations used in this study were 0.83 or $1.66 \mathrm{~mL} / \mathrm{g}$ (soft drink diluted in ultrapure water) or $3.33 \mathrm{~mL} / \mathrm{g}$ (pure soda). The larvae were submitted to chronic exposure (48 hours) until finishing metamorphosis processes. In this study, parallel to wts test, soft drinks toxicity was evaluated in D. melanogaster third stage larvae. Toxicity was measured according to rate of flies that completed metamorphosis process after chronic exposure (48 hours) to different concentrations of soda.

Ultrapure water was used as negative control and 0,1 mM mitomycin $\mathrm{C}$ (MMC) as positive control. The employed mitomycin $\mathrm{C}$ concentration was based in studies of mitotic recombination in D. melanogaster (TSUDA and TAKEDA, 1987) and carcinogenicity assays (ORSOLIN and NEPOMUCENO, 2009; ORSOLIN et al., 2012).

\section{Fly fixation and epithelial tumor analysis}

To epithelial tumor analysis, adult flies emerged from the crossing $m w h+/+m w h \quad \mathrm{x}$ $w t s+/ T M 3, S b^{1}$ were fixed in $70.0 \%$ (v/v) ethanol and analyzed under stereo microscope (Bel® Photonics) in petri dishes with glycerin. Analysis was based on tumor count according with the description of Justice (1995). Results were registered in a standard diagram expressing the number of tumors observed in each part of flies (body, eyes, head, body, wings, legs and halters).

\section{Statistical analysis}

All treatments were performed in three replicates. An average of 300 flies from each treatment were recorded after cross between $m w h / m w h$ and $w t s / T M 3, \mathrm{Sb}^{1}$. $\mathrm{MH}$ progeny flies (mwh $+/$ wts + ) were analyzed to exhaust the stock. In this experiment, for each series tested, of the progeny flies $130 \mathrm{MH}$ both sexes were analyzed.

The frequency of fly with tumors and the frequency of tumors per appendix of fly in each treatment series were compared with the negative control to evaluate tumor induction effects. Statistical differences between epithelial tumors frequency at tested concentrations and negative and positive controls were determined by MannWhitney $\mathrm{U}$ test, nonparametric, using $\mathrm{P}<0.05$ as significance threshold.

Statistical comparisons referring to fly survival test exposed to soft drinks and controls were performed by Chi-square test for independent samples.

\section{RESULTS AND DISCUSSION}

Figure 1 shows the survival rate of $D$. melanogaster descendants from the cross between males of the multiple wing hairs strains and virgin females of the wts/TM3, $s b^{1}$ strains exposed to the soft drinks. None of the soft drinks was toxic to $D$. melanogaster, but even though the survival rate was not significantly reduced, orange, cola zero and lemon-based soft drinks were capable of interfering in the metamorphosis process. 


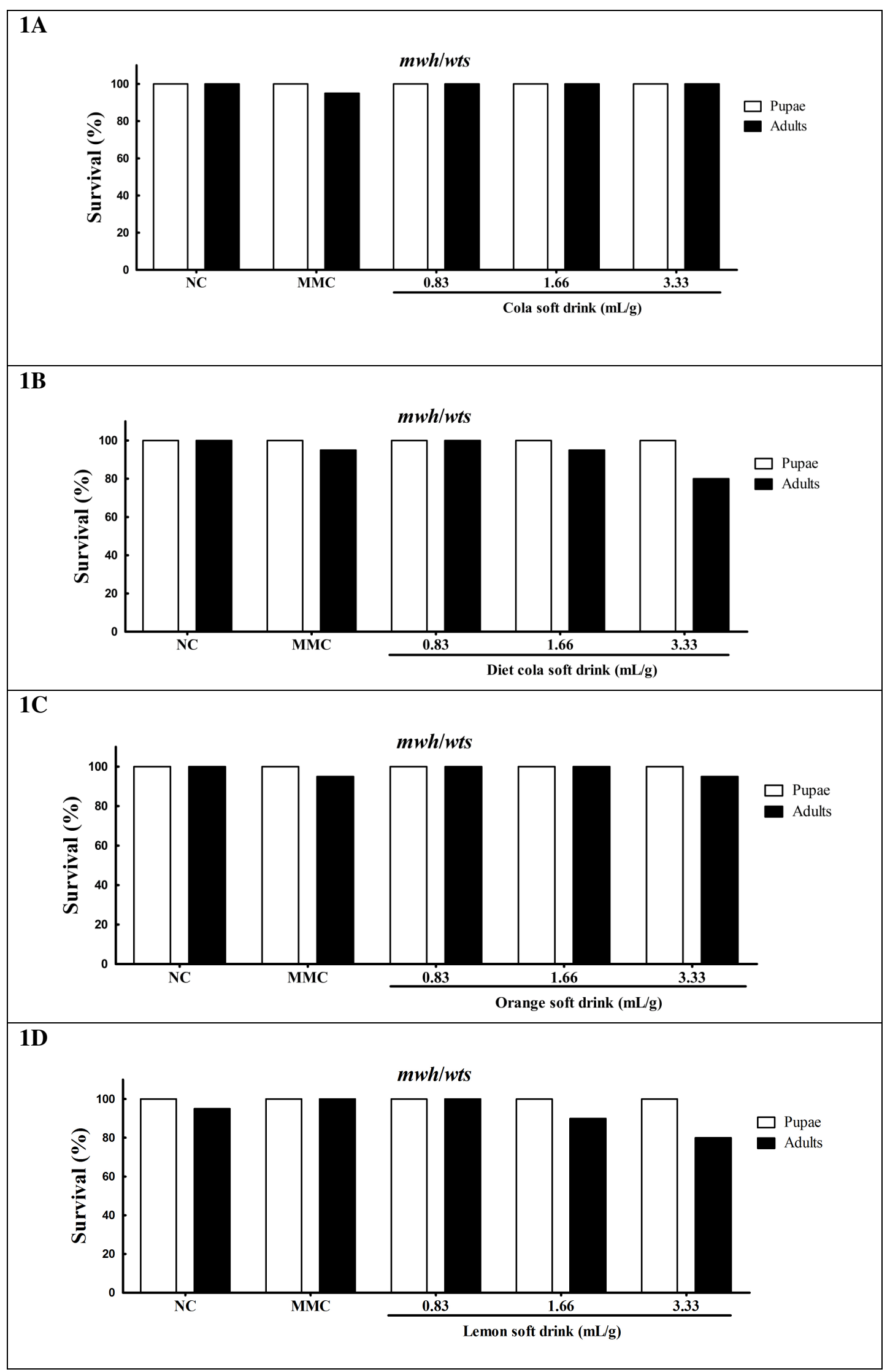

Figure 1. Survival rate of the D. melanogaster progenies resulting from the $m w h / m w h \times w t s / T M 3, s b^{1}$ crosses. NC: Ultrapure water (negative control); MMC: $0.1 \mathrm{mM}$ mitomycin C (positive control); Soft drinks: Cola (1A), Cola diet soft drink (1B), orange soft drink (1C) and Lemon soft drink (1D). 
To assess the carcinogenic potential of the soft drinks used in the present investigation, for each series tested, 130 flies, of both sexes, were analyzed for epithelial tumor presence. The number of flies was evaluated for the presence of a single and more than one tumor. In addition epithelial tumors were quantified in the different appendices (head, eyes, body, legs, wings and halters). The frequency of flies with epithelial tumors and the tumor frequency in the flies appendices were compared to the negative control (ultrapure water). Table 1 shows the results obtained after chronic treatment with Mitomycin C (MMC) and the different concentrations of soft drinks.

As presented in Table 1, the cola-based and orange soft drinks induced heterozygosis loss for the $w t s$ gene in the concentration at $3.33 \mathrm{~mL} / \mathrm{g}$ and differed statistically $(\mathrm{P} \leq 0.05)$ from the control group (ultrapure water). The Statistical difference for the orange-based soft drink $(3.33 \mathrm{~mL} / \mathrm{g})$ was observed in the group of flies with a single tumor (22 flies), and for the group treated with cola-based soft drink, in the group of flies with 2 to 3 tumors (14 flies). Flies treated with lemon-based soft drink and cola zero did not differ statistically $(\mathrm{P}>0.05)$ at any concentrations in the epithelial tumor frequency compared to the negative control. The results obtained in the total frequency of individuals with tumors indicated carcinogenic effect in the flies treated chronically with the cola and orange-based soft drinks in the concentration at $3.33 \mathrm{~mL} / \mathrm{g}$. The lower concentrations showed no carcinogenic effect (Table 1).

Figure 2 shows the epithelial tumor phenotype in the flies treated with the soft drinks. As presented in the Table 2, in all the concentrations and series treated with the soft drinks, the body of the fly was the region with the greatest number of tumors. Statistically significant differences were observed in groups treated with cola-base, diet cola-base or orange-base, soft drinks with concentration of $3.33 \mathrm{~mL} / \mathrm{g}$. These results can be explained by the greater number of cells in the body compared to the appendices, with fewer cells (example: halter). There are higher probabilities of heterozygosis loss of the wts marker in locations with a large number of cells. The results obtained in the present investigation, for tumor frequency in the D. melanogaster appendices are in agreement with data in the literature, which shows a greater tendency to heterozygosis loss of the wts gene in appendices with a greater number of cells (SIDOROV et al., 2001; ORSOLIN; NEPOMUCENO, 2009; SILVA; NEPOMUCENO,
2011; COSTA et al., 2011; FURTADO; NEPOMUCENO, 2012).

Both the negative control (water) and the positive control (MMC) responded reliably to the test. Flies exposed to MMC at $0.1 \mathrm{mM}$ presented high epithelial tumor frequency, differing statistically $(\mathrm{P} \leq 0.05)$ from the negative control in tumor frequency and density (flies with more than two tumors).

Soft drink is a common, non-alcoholic and non-fermented drink, destined for human consumption produced by industrialized processes based on mineral water and sugar. For differently formulated products, different ingredients are used, along with different additives, to produce a high acceptance product by consumers.

Food additives are substances frequently added to foods to maintain or modify their characteristics, nutritional, flavor, appearance, among others and to help in their processing and conservation (LOK et al., 2010).

As presented in their packaging, soft drinks contain a series of food additives, such as preservatives, stabilizers, acidifiers, sweeteners, coloring and aromatizes.

Food coloring is the substance or mixture of substances that have the property to confer or enhance food coloring. As shown in Table 3 sunset yellow is a food coloring used as an ingredient in formulating the orange-based soft drinks. Data in the literature report that sunset yellow is a potent genotoxic agent. Sayed et al (2012) evaluated the effect of sunset yellow in mice. The results showed that sunset yellow had genotoxic effects as indicated by increased frequency of chromosomal aberrations in somatic and germ cells, and by increased morphological sperm abnormalities and DNA fragmentation.

Although the effects of sunset yellow were not directly assessed in the present study, the significant increase in epithelial tumor frequency observed in flies treated with orange-based soft drink in the concentration at $3.33 \mathrm{~mL} / \mathrm{g}$ (Table 1) may have been due to the presence of sunset yellow in its formulation (Table 3). 
Table 1. Frequency of flies with epithelial tumors observed in heterozygous descendants for the D. melanogaster wts tumor suppressor gene treated with Mitomycin C and different concentrations of soft drinks

\section{Frequency of fly with tumor (number of flies with tumor)}

\begin{tabular}{|c|c|c|c|c|c|c|}
\hline $\begin{array}{l}\text { Treatments and concentrations } \\
\qquad(\mathrm{mL} / \mathrm{g})\end{array}$ & $\mathbf{N}^{0}$ of flies & 1 tumor & 2-3 tumors & 4-5 tumors & + 5 tumors & $\begin{array}{c}\text { Total of flies with } \\
\text { tumor }\end{array}$ \\
\hline Negative control & 130 & $0.084(11)$ & $0.023(03)$ & $0.000(00)$ & $0.000(00)$ & 0.107 (14) \\
\hline$M M C$ & 130 & $0.246(32)^{*}$ & $0.192(25)^{*}$ & $0.138(18)^{*}$ & $0.169(22)^{*}$ & $0.746(97)^{*}$ \\
\hline \multicolumn{7}{|l|}{ SF Cola-base } \\
\hline 0.83 & 130 & $0.046(06)$ & $0.015(02)$ & $0.007(01)$ & $0.000(00)$ & $0.069(09)$ \\
\hline 1.66 & 130 & $0.100(13)$ & $0.053(07)$ & $0.007(01)$ & $0.000(00)$ & $0.161(21)$ \\
\hline 3.33 & 130 & $0.161(21)$ & $0.107(14)^{*}$ & $0.000(00)$ & $0.000(00)$ & $0.269(35)^{*}$ \\
\hline \multicolumn{7}{|l|}{ SF diet Cola-base } \\
\hline 0.83 & 130 & $0.061(08)$ & $0.007(01)$ & $0.000(00)$ & $0.000(00)$ & $0.069(09)$ \\
\hline 1.66 & 130 & $0.107(14)$ & $0.000(00)$ & $0.000(00)$ & $0.000(00)$ & $0.107(14)$ \\
\hline 3.33 & 130 & $0.130(17)$ & $0.000(00)$ & $0.000(00)$ & $0.000(00)$ & $0.130(17)$ \\
\hline \multicolumn{7}{|l|}{ SF Orange-base } \\
\hline 0.83 & 130 & $0.076(10)$ & $0.007(01)$ & $0.007(01)$ & $0.00(00)$ & $0.092(12)$ \\
\hline 1.66 & 130 & $0.115(15)$ & $0.015(02)$ & $0.000(00)$ & $0.000(00)$ & $0.130(17)$ \\
\hline 3.33 & 130 & $0.169(22)^{*}$ & $0.053(07)$ & $0.007(01)$ & $0.000(00)$ & $0.230(30)^{*}$ \\
\hline \multicolumn{7}{|l|}{ SF Lemon-base } \\
\hline 0.83 & 130 & $0.076(10)$ & $0.000(00)$ & $0.000(00)$ & $0.000(00)$ & $0.076(10)$ \\
\hline 1.66 & 130 & $0.092(12)$ & $0.007(01)$ & $0.000(00)$ & $0.000(00)$ & $0.100(13)$ \\
\hline 3.33 & 130 & $0.130(17)$ & $0.023(03)$ & $0.007(01)$ & $0.000(00)$ & $0.161(21)$ \\
\hline
\end{tabular}

Statistical diagnostics according to the Mann-Whitney test. Significance level $(\mathrm{P} \leq 0.05)$; * Values different from the negative control; MMC, Mitomycin C $(0.1 \mathrm{mM})$ SF, Soft drinks (concentration in $\mathrm{mL} / \mathrm{g}$ diet to D. melanogaster). 


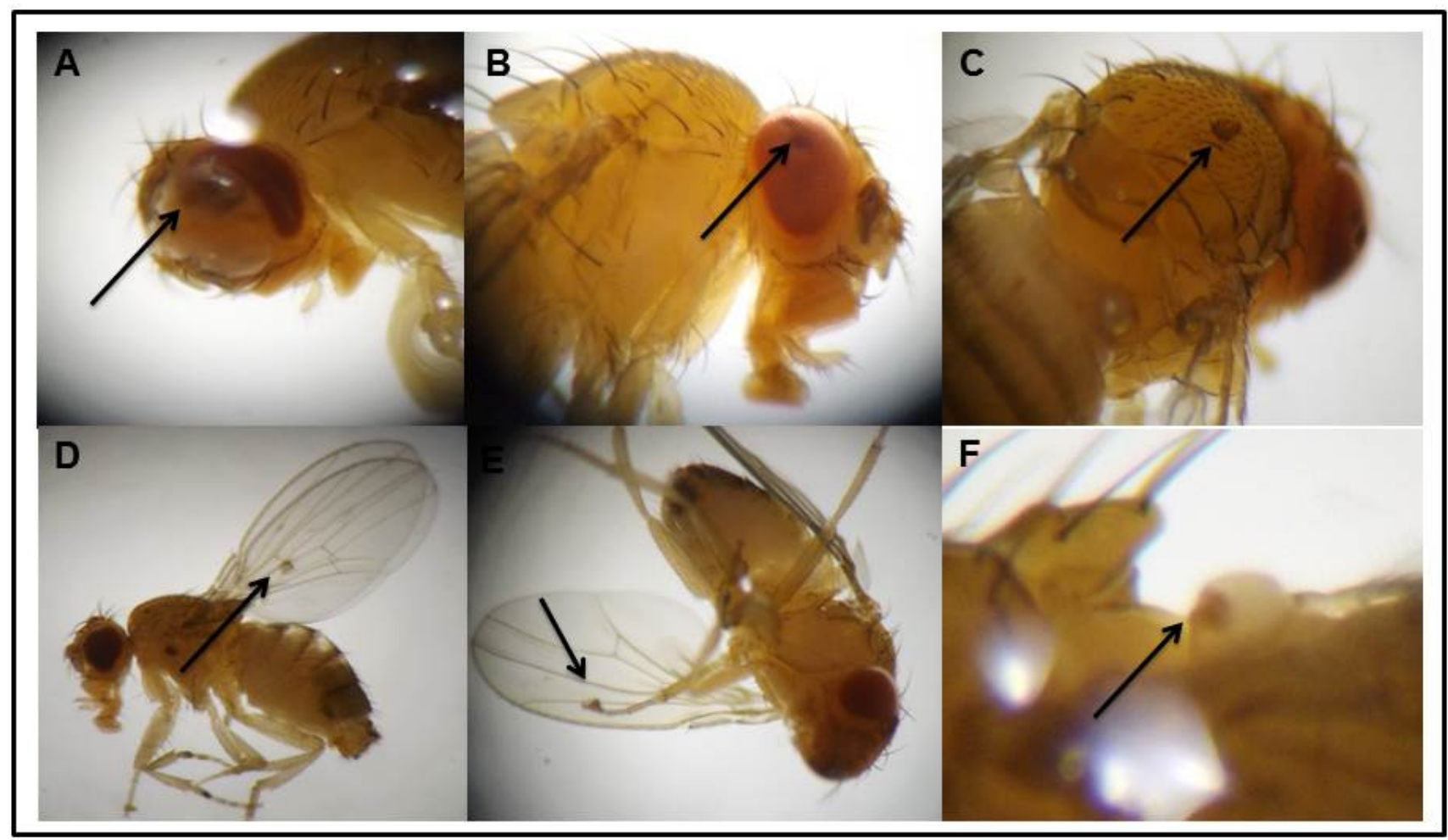

Figure 2. Epithelial tumor observed in D. melanogaster treated with different soft drinks or Mitomycin C. Black arrows indicate the tumor: (A) in the head, (B) in the eye, (C) in the thorax, (D) in the wing, (E) in the leg, and $(F)$ in the halter. 
Table 2. Frequency of tumor clones observed in the appendix of D. melanogaster, heterozygous for the tumor suppressor gene wts treated with mitomycin C and different concentrations of soft drinks

\begin{tabular}{|c|c|c|c|c|c|c|c|c|c|}
\hline Treatment & & $N^{0}$ of flies & & Numbe & of tumor analy & d (total num & er of tumors & & \\
\hline $\begin{array}{c}\text { Soft drinks } \\
(\mathrm{mL} / \mathrm{g})\end{array}$ & $\begin{array}{l}\text { MMC } \\
(\mathrm{mM})\end{array}$ & & Eyes & Head & Wings & Body & Legs & Halters & Total \\
\hline Negative control & - & 130 & $0.007(01)$ & $0.03(04)$ & $0.038(05)$ & $0.046(06)$ & $0.007(01)$ & $0.00(00)$ & $0.013(17)$ \\
\hline $\begin{array}{c}\text { Positive control } \\
\text { SF Cola-base }\end{array}$ & 0,1 & 130 & $0.2(26)^{*}$ & $0.046(06)$ & $1.346(175)^{*}$ & $1.2(156)^{*}$ & $0.2(26)$ & $0.046(06)^{*}$ & $3.038(395)^{*}$ \\
\hline 0.83 & - & 130 & $0.000(00)$ & $0.000(00)$ & $0.023(03)$ & $0.053(07)$ & $0.007(01)$ & $0.000(00)$ & $0.084(11)$ \\
\hline 1.66 & - & 130 & $0.015(02)$ & $0,015(02)$ & $0.053(07)$ & $0.076(10)$ & $0.038(05)$ & $0.007(01)$ & $0.207(27)$ \\
\hline 3.33 & - & 130 & $0.007(01)$ & $0.015(02)$ & $0.00(00)^{*}$ & $0.369(48)^{*}$ & $0.007(01)$ & $0.007(01)$ & $0.407(53)^{*}$ \\
\hline SF diet Cola-base & & & & & & & & & \\
\hline 0.83 & - & 130 & $0.000(00)$ & $0.000(00)$ & $0.023(03)$ & $0.053(07)$ & $0.007(01)$ & $0.000(00)$ & $0.084(11)$ \\
\hline 1.66 & - & 130 & $0.007(01)$ & $0.007(01)$ & $0.015(02)$ & $0.053(07)$ & $0.015(02)$ & $0.007(01)$ & 0.107 (14) \\
\hline 3.33 & - & 130 & $0.00(00)$ & $0.015(02)$ & $0.007(01)$ & $0.107(14)^{*}$ & $0.00(00)$ & $0.00(00)$ & $0.138(18)$ \\
\hline SF Orange-base & & & & & & & & & \\
\hline 0.83 & - & 130 & $0.015(02)$ & $0.000(00)$ & $0.038(05)$ & $0.053(07)$ & $0.015(02)$ & $0.00(00)$ & $0.123(16)$ \\
\hline 1.66 & - & 130 & $0.000(00)$ & $0.000(00)$ & $0.038(05)$ & $0.076(10)$ & $0.030(04)$ & $0.007(01)$ & $0.153(20)$ \\
\hline 3.33 & - & 130 & $0.023(03)$ & $0.038(05)$ & $0.076(10)$ & $0.146(19)^{*}$ & $0.015(02)$ & $0.015(02)$ & $0.315(41)^{*}$ \\
\hline SF Lemon-base & - & & & & & & & & \\
\hline 0.83 & - & 130 & $0.000(00)$ & $0.007(01)$ & $0.030(04)$ & $0.030(04)$ & $0.007(01)$ & $0.000(00)$ & $0.076(10)$ \\
\hline 1.66 & - & 130 & $0.007(01)$ & $0.000(00)$ & $0.038(05)$ & $0.046(06)$ & $0.015(02)$ & $0.000(00)$ & $0.107(14)$ \\
\hline 3.33 & - & 130 & $0.015(02)$ & $0.03(04)$ & $0.038(05)$ & $00.076(10)$ & $0.046(06)$ & $0.00(00)$ & $0.207(27)$ \\
\hline
\end{tabular}

Statistical diagnostics according to the Mann-Whitney test. Significance level ( $\mathrm{P} \leq 0.05)$; ${ }^{*}$ Values considered different from the negative control.

MMC, Mitomycin C (0.1 mM); SF, Soft drinks (concentration in $\mathrm{mL} / \mathrm{g}$ diet to D. melanogaster) 
Table 3. Declared ingredients used in soft drinks formulation

\section{Ingredients}

\begin{tabular}{|c|c|c|c|c|c|c|c|c|}
\hline $\begin{array}{l}\text { Soft } \\
\text { drinks }\end{array}$ & Base & Coloring & Sweetener & Acidulant & Acidity corretor & Stabilizer & Preservatives & Antioxidant \\
\hline Cola & $\begin{array}{l}\text { Carbonated } \\
\text { water, sugar, } \\
\text { cola nut } \\
\text { extract, } \\
\text { caffeine }\end{array}$ & Caramel IV & $\mathrm{Nd}$ & Phosphoric acid & $\mathrm{Nd}$ & $\mathrm{Nd}$ & $\mathrm{Nd}$ & $\mathrm{Nd}$ \\
\hline Diet cola & $\begin{array}{c}\text { Carbonated } \\
\text { water, sugar, } \\
\text { cola nut } \\
\text { extract, } \\
\text { caffeine }\end{array}$ & Caramel IV & $\begin{array}{l}\text { Sodium } \\
\text { cyclamate, } \\
\text { Acesulfame } \\
\text { potassium, } \\
\text { Aspartame }\end{array}$ & Phosphoric acid & Sodium citrate & $\mathrm{Nd}$ & Sodium benzoate & Ascorbic acid \\
\hline Orange & $\begin{array}{c}\text { Water, } \\
\text { concentrated } \\
\text { orange juice, } \\
\text { sugar, } \mathrm{CO}_{2}\end{array}$ & $\begin{array}{c}\text { Sunset } \\
\text { yellow FCF }\end{array}$ & $\mathrm{Nd}$ & Citric acid & Citric acid & $\begin{array}{l}\text { Sucrose acetate } \\
\text { isobutyrate } \\
\text { Dioctyl sodium } \\
\text { sulfosuccinate }\end{array}$ & $\begin{array}{l}\text { Sodium benzoate } \\
\text { Potassium sorbate }\end{array}$ & $\mathrm{Nd}$ \\
\hline Lemon & $\begin{array}{l}\text { Water, sugar, } \\
\text { lemon juice }\end{array}$ & $\mathrm{Nd}$ & $\mathrm{Nd}$ & Citric acid & Sodium citrate & $\mathrm{Nd}$ & $\begin{array}{l}\text { Potassium sorbate } \\
\text { Sodium benzoate }\end{array}$ & $\mathrm{Nd}$ \\
\hline
\end{tabular}


Caramel coloring is one of the most used colorings in the food sector. It is commonly found in cola-based soft drinks and attributes a brownish coloring to the product (KAMUF et al., 2003). Its synthesis from ammonia compounds can result in the formation of 4-methylimidazole (4-MI) as byproduct (MOON; SHIBAMOTO, 2011). Exposure to 4-MI of the human population is associated to caramel colorings III and IV and this compound can increase the risk of cancer (AUBREY, 2014; CONSUMER REPORTS, 2014). The presence of 4-MI has already been confirmed in different brands of cola-based soft drinks (SMITH et al., 2015).

A study carried out in 2011 by the National Toxicology Program of the United States Government informed carcinogenic effects of 4-MI, based on the increase in adenomas and carcinomas in mice lungs (NTP, 2007). Subsequently the International Agency for Cancer Research of the WHO (World Health Organization) included 4-MI on the list of substances possibly carcinogenic to humans (IARC, 2010). When administered to F344/N rats and B6C3F1 mice at doses of $260 \mathrm{ug} / \mathrm{kg}$ and $170 \mathrm{ug} / \mathrm{kg}$, respectively, the 4-MI compound presented tumorigenic effect (CHAN et al., 2008).

However, there are few studies on the action mechanisms of the compound. Thus the caramel coloring IV found in cola-based soft drink (Table 3) may have been responsible for the increase in tumor frequency in D. melanogaster (Table 1) when exposed to cola-based soft drink, through the 4-MI byproduct.

Artificial sweeteners are one of the main classes of additives that include aspartame, cyclamate and saccharine, called first-generation sweeteners, and the others knowed as secondgeneration sweeteners, such as sucralose and acesulfame potassium (WEINRAUCH; DIEHL, 2004). Aspartame can be found in sugar-free soft drink ("diet" or "zero') (Table 3). This compound is hydrolyzed to methanol and aspartyl-phenylalanine in the gut, and then hydrolyzed to aspartate and phenylalanine.

The methanol generated by the hydrolyzed aspartame is converted to formaldehyde that can accumulate in the cells and induce carcinogenic states (SCHWARTZ, 1999).

Abhilash et al. (2013) showed the effects of chronic aspartame ingestion in Wistar rats which resulted in imbalance in the oxidative states in the brain of the exposed, through a glutathionedependent system. In spite of controversial results for mutagenic and genotoxic profile in different study models, Yılmaz and Uçar (2014) in a revision highlight the genotoxic effects of aspartame, characterizing it as a moderate carcinogenic agent for humans, with positive results for $45 \%$ of the epidemiological studies. Aspartame was described as being an inducer of angiogenicity by Alleva et al. (2011). According to these authors aspartame can lead to the formation of new blood vessels by increase in IL-6 and VEGF, and slight increase in the production of oxygen reactive species (ROS). Angiogenesis is essential for tumor cell invasion and tumor mass growth (FOLKMAN, 1995).

Table 3 shows that even though caramel coloring IV and aspartame were present in its formulation, the diet cola-based soft drink included in the diet of $D$. melanogaster trans-heterozygote for the wts tumor suppressor gene, was not capable of inducing heterozygosis loss of this marker (Tables 1 and 2). These results can probably be explained by three different factors:

(1) For commercial reasons, even when informed the ingredients used in the beverage, it is not disclosed the concentrations of each ingredient. The concentrations of caramel coloring IV used in cola zero-based soft drink can be different from those used in the traditional cola.

(2) The sodium citrate is present both in the diet cola-based soft drink (zero) and the lemonbased soft drink (Table 3). Sodium citrate is a saline flavored salt, used as an additive for different functions, such as acidity corrector, flavor enhancer and to prevent enzymatic darkening in fresh foods. This compound, in gold nanoparticles was responsible for increasing their cytotoxic effect in epithelial and endothelial human cell cultures, reducing their viability (FREESE et al., 2012). Figure 1 showed a $20 \%$ reduction in the survival of the flies treated chronically with $3.33 \mathrm{~mL} / \mathrm{g}$ of cola zero. The sodium citrate probably increased the cytotoxic effect of the other ingredients and killed the $D$. melanogaster cells. With cell death phenotypic identification of tumors is compromised.

(3) Table 3 shows that the zero cola-based soda presents ascorbic acid as antioxidant agent. The presence of this ingredient may have acted as a counterbalance for oxidative stress, and acting in cell protection against oxygen reactive species (NUNES et al., 2015; BHUSAL et al., 2014; DU et al., 2014) and as preventive ingredient in diseases related to genetic instability (COVARRUBIASPINTO et al., 2015; TASHIMA et al., 2015; HIPOLITO et al., 2015; FINCK et al., 2014).

Considering the oxidative protective effect, the increase of antioxidant formulations in soft drinks can be a great alternative to minimize the 
effects of harmful components used in the formulation.

The lemon-based soft drink assessed in the present study did not present either caramel coloring, sunset yellow or aspartame sweetener (Table 3) in its composition, which is in concordance with the result of low epithelial tumor frequency observed in $D$. melanogaster treated with this beverage (Tables 1 and 2).

The results of present study indicate that the ingestion of any soft drink is not related straightly to carcinogenic states, however, we warn against intense and indiscriminate consumption of this beverage, because it can cause a lot of diseases related to obesity, glycemia and genetic instability.

\section{CONCLUSION}

Cola-based and orange-based soft drinks demonstrated carcinogenic effect in the most concentrated dose of this work $(3.33 \mathrm{~mL} / \mathrm{g})$, but further studies using other tests, systems and organisms are necessary to get more information on the toxic kinetics of the substances in humans.

\section{Conflict of interests}

The authors declare no conflict of interest.

\section{ACKNOWLEDGEMENTS}

The authors are grateful to the First Summer Course in Genetics and Biochemistry accomplished at Federal University of Uberlândia (UFU), Brazil and to the financial agencies, CAPES, CNPq and FAPEMIG.

RESUMO: Refrigerantes são bebidas industrializadas não fermentadas, livre de álcool, carbonatadas, ricas em aromas artificiais e açúcar. O consumo intenso dessas bebidas pode estar relacionada à doenças não herdáveis como, cáries, quadros alérgicos, formação de celulite e estrias cutâneas, alterações gastrointestinais, diabetes e câncer. O objetivo desse trabalho foi avaliar o potencial carcinogênico de diferentes concentrações de refrigerantes produzidos no município de Uberlândia, Estado de Minas Gerais, Brasil. Foi realizado o Teste de Detecção de Tumor Epitelial em Drosophila melanogaster. Larvas de terceiro estágio descendentes do cruzamento entre fêmeas virgens $w t s / T M 3, s b^{1}$ e machos $m w h / m w h$ de $D$. melanogaster foram tratadas com diferentes concentrações $(0,83 ; 1,66$ ou $3,33 \mathrm{~mL} / \mathrm{g})$ de refrigerantes à base de cola, diet cola, laranja e limão. Os resultados mostraram aumento na frequência de tumor epitelial em moscas tratadas $3,33 \mathrm{~mL} / \mathrm{g}$ de refrigerantes à base de cola e de laranja, quando comparados ao controle negativo. Os refrigerantes diet cola e limão não provocaram aumento na frequência de tumor epitelial em D. melanogaster. Em conclusão, nessas condições experimentais, os refrigerantes à base de cola e laranja mostraram potencial carcinogênico em células somáticas de D. melanogaster na concentração de $3,33 \mathrm{~mL} / \mathrm{g}$.

PALAVRAS-CHAVE: Mutagenicidade. Wts. Warts. Drosophila melanogaster.

\section{REFERENCES}

ABHILASH, M.; SAUGANTH PAUL, M. V.; MATHEWS, V.; VARGHESE, R. H. N. Long-term consumption of aspartame and brain antioxidant defense status. Drug and Chemical Toxicology, New York, v. 36, p. 135-140, 2013. http://dx.doi.org/10.3109/01480545.2012.658403

ABIR. Associação Brasileira das Indústrias de Refrigerantes e Bebidas Alcoólicas. Disponível em: http://abir.org.br/a-abir/. Acessado em 11/08/2015.

ALLEVA R.; BORGHI B, SANTARELLI, L.; STRAFELLA, E.; CARBONARI, D.; BRACCI, M.; TOMASETTI, M. In vitro effect of aspartame in angiogenesis induction. Toxicology in Vitro, Oxford, v. 25, p. 286-293, 2011. http://dx.doi.org/10.1016/j.tiv.2010.09.002

ANDRADE, H.H.R.; LEHMANN, M. Teste para a detecção de mutação e recombinação somática (SMART) em Drosophila melanogaster. In: RIBEIRO, R.L.; SALVADORI, D. M. F.; MARQUES, E. K. Mutagênese Ambiental. ULBRA, Canoas, v. 1, p. 281-307, 2003. 
AUBREY, A. (2014) Potential Carcinogen in Colas Has FDA Reviewing Data. Disponível em: http://www.npr.org/blogs/thesalt/2014/01/23/265245172/potential-carcinogen-in-colas-has-fda-reviewing-data. Acessado em: agosto de 2015.

BOWMAN, S. A. Beverage choices of young females: changes and impact on nutrient intakes. Journal of the American Dietetic Association, Chicago, v. 102, n. 1, p. 1234-1239, 2002. http://dx.doi.org/10.1016/S00028223(02)90273-7

BHUSAL, A.; JAMARKATTEL, N.; SHRESTHA, A.; LAMSAL, N. K.; SHAKYA, S.; RAJBHANDARI, S. Evaluation of antioxidative and antidiabetic activity of bark of holarrhena pubescens wall. Journal of Clinical and Diagnostic Research, Delhi, v. 8, n. 9, p. 5- 8, 2014. http://dx.doi.org/10.7860/jcdr/2014/7803.4863

CARMO, M. B. Consumo de doces, refrigerantes e bebidas com adição de açúcar entre adolescentes da rede pública de ensino de Piracicaba, São Paulo. Revista Brasileira de Epidemiologia, São Paulo, v. 9, n. 1, p.121130, 2006. http://dx.doi.org/10.1590/S1415-790X2006000100015

CHAN, P. C.; HILL, G. D.; KISSLING, G. E.; NYSKA, A. Toxicity and carcinogenicity studies of 4methylimidazole in F344/N rats and B6C3F1 mice. Archives of Toxicology, New York, v. 82, p. 45-53, 2008. http://dx.doi.org/10.1007/s00204-007-0227-0 http://dx.doi.org/10.1007/s00204-007-0222-5

CHERMONT, P. E. C.; DA COSTA, R. S.; SICHIERI, R.; PEREIRA, R. A.; DA VEIGA, G. V. Meal consumption patterns and anthropometric measurements in adolescents from a low socioeconomic neighborhood in the metropolitan area of Rio de Janeiro, Brazil. Appetite, London, v. 52, n. 3, p. 735-739, 2009. http://dx.doi.org/10.1016/j.appet.2009.03.017

Consumer Reports (2014) Caramel Color: The Health Risk That May Be in Your Soda. Disponível em: http://www.consumerreports.org/cro/news/2014/01/caramel-color-the-health-risk-that-may-be-in-yoursoda/index.htm. Acessado em: agosto de 2015.

COSTA, R. M. A.; MENK, C. F. M. Biomonitoramento de mutagênese ambiental. Biotecnologia: Ciência e Desenvolvimento, Brasília, v. 3, n. 12, 2000. http://dx.doi.org/10.4238/2011.December.22.1

COSTA, W. F.; OLIVEIRA, A. B.; NEPOMUCENO, J. C. Lapachol as an epithelial tumor inhibitor agent in Drosophila melangaster heterozygote for tumor supressor gene wts. Genetics and Molecular Research, Ribeirão Preto, v. 10, p. 3236-3245, 2011. http://dx.doi.org /10.4238/2011.December.22.1

COVARRUBIAS-PINTO, A.; MOLL, P.; SOLIS-MALDONADO, M.; ACUNA, A. I.; RIVEROS, A.; MIRO, M. P.; PAPIC, E.; BELTRAN, F. A.; CEPEDA, C.; CONCHA, I.; BRAUCHI, S.; CASTRO, M. A. Beyond the redox imbalance: Oxidative stress contributes to an impaired GLUT3 modulation in Huntington's disease. Free Radical Biology and Medicine, New York, v. 89, p. 1085-96, 2015.

http://dx.doi.org/10.1016/j.freeradbiomed.2015.09.024

DU, L.; KING, J. B.; CICHEWICZ, R. H. Chlorinated polyketide obtained from a Daldinia sp. treated with the epigenetic modifier suberoylanilide hydroxamic acid. Journal of Natural Products, Cincinnati, v. 77, n. 11, p. 2454-2458, 2014. http://dx.doi.org/10.1021/np500522z

FINCK, H.; HART, A. R.; JENNINGS, A.; WELCH, A. A. Is there a role for vitamin C in preventing osteoporosis and fractures? A review of the potential underlying mechanisms and current epidemiological evidence. Nutrition Research Reviews, Cambridge, v. 27, n. 2, p. 268-283, 2014.

http://dx.doi.org/10.1017/S0954422414000195

FOLKMAN, J. Angiogenesis in cancer, vascular, rheumatoid and other diseases. Nature Medicine, New York, v. 1, p. 27-31, 1995. http://dx.doi.org/10.1038/nm0195-27 
FRANK, S. A. Evolution in health and medicine sackler colloquium: somatic evolutionary genomics: mutations during development cause highly variable genetic mosaicism with risk of cancer and neurodegeneration.

Proceedings of the National Academy Sciences of the United States of America, Washington, v. 107, n. 1 p. 1725-30, 2010. http://dx.doi.org/10.1073/pnas.0909343106

FREESE, C.; UBOLDI, C.; GIBSON, M. I.; UNGER, R. E.; WEKSLER, B. B.; ROMERO, I. A.; COURAUD, P. O.; KIRKPATRICK, C. J. Uptake and cytotoxicity of citrate-coated gold nanospheres: Comparative studies on human endothelial and epithelial cells. Particle and Fibre Toxicology, Londom, v. 9, n. 23, 1-11, 2012. http://dx.doi.org/10.1186/1743-8977-9-23

FURTADO, S. G.; NEPOMUCENO, J. C. Redução de tumor epitelial em Drosophila melanogaster, pela enzima metaloprotease isolada da peçonha da serpente Bothrops pauloensis, por meio do teste wts (Warts). Perquirere, Patos de Minas, v. 9, p. 224-240, 2012.

GARCIA, G. C.; GAMBARDELLA, A. M.; FRUTUOSO, M. F. Nutritional status and food consumption of adolescents registered at a center of youth from the city of São Paulo, Brazil. Revista de Nutrição, Campinas, v. 16, n. 1, p. 41-50, 2003. http://dx.doi.org/10.1590/S1415-52732003000100005

GRIMM, G. C.; HARNACK, L.; STORY, M. Factors associated with soft drink consumption in school-aged children. Journal of the American Dietetic Association, v. 104, n. 8, p. 1244-1249, 2004.

HIB, J and ROBERTIS, E. M. F. Bases da biologia celular e molecular. 3 ed. Rio de Janeiro, Brasil: Guanabara Koogan. 1998. http://dx.doi.org/10.1016/j.jada.2004.05.206

HIPOLITO, U. V.; CALLERA, G. E.; SIMPLICIO, J. A.; DE MARTINIS, B. S.; TOUYZ, R. M.; TIRAPELLI, C. R. Vitamin C prevents the endothelial dysfunction induced by acute ethanol intake. Life Sciences, Elmsford, v. 141, p. 99-107, 2015. http://dx.doi.org/10.1016/j.lfs.2015.09.006

International Agency for Research on Cancer (2010) 4-Methylimidazole. Disponível em: http://www.iarc.fr/. Acessado em: agosto de 2015.

JUSTICE, R. W.; ZILIAN, O.; WOODS, D. F.; NOLL, M.; BRYANT, P. J. The Drosophila tumor suppressor gene Warts encodes a homolog of human myotonic dystrophy kinase and is required for the control of cell shape and proliferation. Genes and Development, Cold Spring Harbor, v. 9, n. 5, p. 534-546, 1995. http://dx.doi.org/10.1101/gad.9.5.534

KAMUF, W.; NIXON, A.; PARKER, O.; BARNUM, G. C. Overview of Caramel Colors. Cereal Foods World, Minneapolis, v. 48, p. 64-69, 2003.

KELLER, K. L.; KIRZNER, J.; PIETROBELLI, A.; ST-ONGE, M. P.; FAITH, M. S. Increased sweetened beverage intake is associated with reduced milk and calcium intake in 3- to 7-year-old children at multi-item laboratory lunches. Journal of the American Dietetic Association, Chicago, v. 109, n. 3, p. 497-501, 2009. http://dx.doi.org/10.1016/j.jada.2008.11.030

KIM, S. I.; J. W.; JUNG, J. W.; A. H. N, Y. J.; RESTIFO, L. L.; KWON, H. W. Drosophila as a model system for studying lifespan and neuroprotective activities of plant-derived compounds. Jounal of Asia-Pacific Entomology, v. 14, n. 4, p. 509-517, 2011. http://dx.doi.org/10.1016/j.aspen.2011.07.001

LOK, K. Y. W.; CHUNG, W. Y.; IRIS, F. F. Color additives in snack foods consumed by primary school children in Hong Kong. Food Additives and Contaminants, London, v. 3, n. 3, p. 148-155, 2010. http://dx.doi.org/10.1080/19393210.2010.509815

LOPES, A. A.; OLIVEIRA, A. M.; PRADO, C. B. C. Principais genes que participam da formação de tumores. Revista de Biologia e Ciências da Terra, Sergipe, v. 2, n. 2, p. 1-7, 2002. 
LOURO, I. D; LLERENA Jr., J. C.; MELO, M. S. V.; ASHTON-PROLLA, P.; CNFORTI, N. F. Genética Molecular do Câncer. 2.ed. São Paulo: MSG Produção Editorial, 2002.

LUDWIG, D. S.; PETERSON, K. E.; GORTMAKER, S. L. Relation between consumption of sugar-sweetened drinks and childhood obesity: a prospective, observational analysis. The Lancet, London, v. 357, n. 1, p. 505508, 2001. http://dx.doi.org/10.1016/S0140-6736(00)04041-1

MACHADO, N. M.; LOPES, J. C.; SATURNINO, R. S.; FAGAN, E. B.; NEPOMUCENO, J. C. Lack of Mutagenic effect by multi-walled functionalized carbono nanotubes in the somatic cells of Drosophila melanogaster. Food and Chemical Toxicology, Oxford, v. 62, n. 1, p. 355-360, 2013.

http://dx.doi.org/10.1016/j.fct.2013.08.051

MOON, J. K.; SHIBAMOTO, T. Formation of Carcinogenic 4(5)-Methylimidazole in Maillard Reaction Systems. Journal of Agricultural and Food Chemistry, Easton, v. 59, p. 615-618, 2011.

http://dx.doi.org/10.1021/jf104098a

National Toxicology Program (2007) NTP Technical Report on the Toxicology and Carcinogenesis Studies of 4-Methylimidazole (CAS No. 822-36-6) in F344/N Rats and B6C3F1 Mice (Feed Studies). Disponível em: http://ntp.niehs.nih.gov/ntp/htdocs/lt_rpts/tr535.pdf. Acessado em: Agosto de 2015.

NIELSEN, S. J.; POPKIN, B. M. Changes in beverage intake between 1977 and 2001. American Journal Preventive Medicine, Easton, v. 27, p. 205-210, 2004. http://dx.doi.org/10.1016/j.amepre.2004.05.005

NISHIYAMA, Y.; HIROTA, T.; MORISAKI, T.; HARA, T.; MARUMOTO, T.; IADA, S.; MAKINO, K.; YAMAMOTO, H.; HIRAOKA, T.; KITAMURA, N.; SAYA.; H. A human homolog Drosophila warts supressor, h-warts, localized to mitotic apparatus and specifically phosphorylated during mitosis. Febs Letters, Amsterdam, v. 459, n. 2, p. 159-165, 1999. http://dx.doi.org/10.1016/S0014-5793(99)01224-7

NUNES, G. B.; COSTA, L. M.; GUTIERREZ, S. J.; SATYAL, P.; DE FREITAS, R. M. Behavioral tests and oxidative stress evaluation in mitochondria isolated from the brain and liver of mice treated with riparin A. Life Sciences, Elmsford, v. 121, p. 57-64, 2015. http://dx.doi.org/10.1016/j.lfs.2014.11.018

OLIVEIRA, A. C. S. A.; SANTOS, E. P.; SILVA, M. S; VIEIRA, T. P. R.; SILVA, S. M. Impacto do consumo de refrigerantes na saúde de escolares do colégio gissoni. Revista Eletrônica Novo Enfoque, Rio de Janeiro, v. 12, n. 12, p. 68-79, 2011.

ORSOLIN, P. C.; NEPOMUCENO, J. C. Potencial carcinogênico do açafrão (Curcuma Longa L) identificado por meio do teste para detecção de clones de tumor em Drosophila melannogaster. Perquirere, Patos de Minas, v. 6, p. 55-69, 2009.

ORSOLIN, P. C.; SILVA-OLIVEIRA, R. G.; NEPUMOCENO, J. C. Assessment of the mutagenic, recombinagenic and carcinogenic potential of orlistat in somatic cells of Drosophila melanogaster. Food and Chemical Toxicology, Oxford, v. 50, n. 8, p. 2598-2604, 2012. http://dx.doi.org/10.1016/j.fct.2012.05.008

READ, A. P.; STRACHAN, T. Genética molecular humana. 2 ed. Porto Alegre, Editora Artmed, 2002.

n 744, p. 145-153, 2012. http://dx.doi.org/10.1016/j.mrgentox.2012.02.003

SCHWARTZ, G. R. Aspartame and breast and other cancers. The Western Journal of Medicine, v. 171, p. 300-301, 1999.

SIDOROV, R. A.; UGNIVENKO, E. G.; KHOVANOVAE, E. M.; BELISTSKY, G. A. Induction of tumor clones in Drosophila melanogaster wts/+ heterozygotes with chemical carcinogeneses. Mutation Research, Amsterdam, v. 498, n.1, p. 181-191, 2001. http://dx.doi.org/10.1016/S1383-5718(01)00277-7 
SILVA, L. M.; NEPOMUCENO, J. C. Efeito modulador da polpa da graviola (Annona muricata) sobre a carcinogenicidade da mitomicina $\mathrm{C}$, avaliado por meio do teste para detecção de clones de tumor (warts) em Drosophila melanogaster. Perquirere, Patos de Minas, v. 8, p. 80-94, 2011.

SMITH, T. J. S.; WOLFSON, J. A.; JIAO, D.; CRUPAIN, M. J.; RANGAN, U.; SAPKOTA, A.; BLEICH, S. N.; NACHMAN, K. E. Caramel Color in Soft Drinks and Exposure to 4- Methylimidazole: A Quantitative Risk Assessment. PLOS ONE, V. 10, n. 2, 2015. http://dx.doi.org/10.1371/journal.pone.0118138

TASHIMA, C. M.; HERMES-ULIANA, C.; PERLES, J. V.; DE MIRANDA NETO, M. H.; ZANONI, J. N. Vitamins $\mathrm{C}$ and $\mathrm{E}$ (ascorbate/alpha-tocopherol) provide synergistic neuroprotection in the jejunum in experimental diabetes. Pathophysiology, Basel, v. 22, n. 4, p. 241-248, 2015.

http://dx.doi.org/10.1016/j.pathophys.2015.09.003

TSUDA, H.; TAKEDA, N. Effect of tumor promoter TPA on spontaneous and Mitomycin C induced mitotic recombination in Drosophila melanogaster. Mutation Research, Amsterdam, v. 189, p. 375-379, 1987. http://dx.doi.org/10.1016/0165-1218(87)90045-0

WEIHRAUCH, M. R.; DIEHL, V. Artificial sweeteners - do they bear a carcinogenic risk? Annals of Oncology, Dordrecht, Holanda, NL, v. 15, n. 10, p. 1460-1465, 2004. http://dx.doi.org/10.1093/annonc/mdh256

XU, T.; WANG, W.; ZHANG, S.; STEWART, R. A.; YU, W. Identifying tumor supressors in genetic mosaics: the Drosophila lats gene encodes a putative protein kinase. Development, Cambridge, v. 12, n. 4, p. 1053$1063,1995$.

YILMAZ, S and UÇAR, A. A review of the genotoxic and carcinogenic effects of aspartame: does it safe or not? Cytotechnology, v. 66, n. 6, p. 875-81, 2014. http://dx.doi.org/10.1007/s10616-013-9681-0 